Note

\section{Detoxification of Sulfite Produced during the Oxidation of Elemental Sulfur by Thiobacillus ferrooxidans}

\author{
Tsuyoshi Sugio, Masako Noguchi \\ and Tatsuo TANO \\ Department of Agricultural Chemistry, \\ Faculty of Agriculture, \\ Okayama University, \\ Okayamá 700, Japan
}

Received June 27, 1986

It is important to study the mechanism of sulfur oxidation in Thiobacillus ferrooxidans because this bacterium is a very valuable microorganism for the bacterial leaching of sulfide ores, and for the cycling of reduced sulfur compounds in the environment. Many investigators have reported on the enzymes involved in sulfur oxidation by $T$. ferrooxidans, ${ }^{1 \sim 8)}$ and a sulfur oxidation route similar to that in Thiobacillus thiooxidans ${ }^{9,10)}$ has been reported for T. ferrooxidans. ${ }^{2,5)}$

We recently reported the presence of a ferric-ion reducing system (FIR system) that catalyzes the reduction of ferric ions $\left(\mathrm{Fe}^{3+}\right)$. with elemental sulfur in a pure strain of $T$. ferrooxidans AP19-3, and proposed a new sulfur oxidation route that comprises both FIR and ironoxidizing systems. ${ }^{11)} \mathrm{By}$ using a potent trapping reagent for $\mathrm{Fe}^{2+}$, we showed that under aerobic conditions in the absence of cyanide, $\mathrm{Fe}^{2+}$ was produced as an intermediate during the oxidation of elemental sulfur by $T$. ferrooxidans AP19-3. ${ }^{12}$ The results strongly support the possibility that both FIR and iron-oxidizing systems operate in the growth of this bacterium on a sulfur-salts medium. The involvement of the FIR system in sulfur oxidation by this strain was further supported by the results of studies showing growth inhibition of this strain by heavy metals. Cupric ions $\left(\mathrm{Cu}^{2+}\right)$ competed with $\mathrm{Fe}^{3+}$ at the active site of the FIR system, and this competitive inhibition was suggested to be the main cause of the inhibition of sulfur oxidation by $\mathrm{Cu}^{2+} \cdot{ }^{13)}$

It was found that when $T$. ferrooxidans AP19-3 was incubated with elemental sulfur and $\mathrm{Fe}^{3+}$ under anaerobic conditions or under aerobic conditions in the presence of $5 \mathrm{~mm}$ cyanide, a small amount of sulfite was accumulated in the reaction mixture at $\mathrm{pH} 3.0$, and short treatment of intact cells of the strain with externally added phenol or sulfite completely destroyed the cells' FIR system. ${ }^{11)}$ In this report, we demonstrate that (i) $T$. ferrooxidans AP19-3 produced a large amount of sulfite in the reaction mixture when intact cells were incubated with elemental sulfur under aerobic conditions in the absence of cyanide at such a high $\mathrm{pH}$ that the iron oxidase of the cells scarcely operates (above $\mathrm{pH} 5.0$ ), (ii) incubation treatment of the cells with sulfite produced by themselves during the oxidation of elemental sulfur markedly destroyed both the iron-oxidizing and FIR systems in the cells, and (iii) the inhibition of cell growth in a sulfur-salts medium by externally added sulfite was markedly abolished by adding $\mathrm{Fe}^{3+}$ to the medium.

Under aerobic conditions in the absence of $\mathrm{Fe}^{3+}$ and cyanide, washed intact cells ( $5 \mathrm{mg}$ of protein) of $T$. ferrooxidans AP19-3 grown in $\mathrm{FeSO}_{4} \cdot 7 \mathrm{H}_{2} \mathrm{O}(3 \%$ )-salts medium were incubated with $2 \%$ elemental sulfur in $10 \mathrm{ml}$ of $0.5 \mathrm{M} \cdot \beta$-alanine- $\mathrm{SO}_{4}^{2-}$ buffer at $\mathrm{pH} 3.0,4.0,5.0,6.0$ and 6.5 , respectively. As shown in Fig. 1, sulfite was rapidly accumulated in each of the reaction mixtures under aerobic conditions in the absence of cyanide. The amount of sulfite accumulated at $\mathrm{pH} 5.0,6.0$ and 6.5 was larger than that accumulated at $\mathrm{pH} 3.0$ and 4.0. After 2 hours incubation at $\mathrm{pH} 5.0,6.0$ and 6.5 , the concentration of sulfite in the reaction mixtures remained at a constant level. In contrast, the sulfite produced in the reaction mixture at $\mathrm{pH} 3.0$ completely disappeared within $30 \mathrm{~min}$. This rapid decrease in sulfite at $\mathrm{pH} 3.0$ was markedly inhibited by adding $5 \mathrm{~mm}$ cyanide, which completely inhibits the iron oxidase of the strain. In addition to chemical decomposition, some parts of the sulfite produced seem to be decomposed by the iron oxidase of the

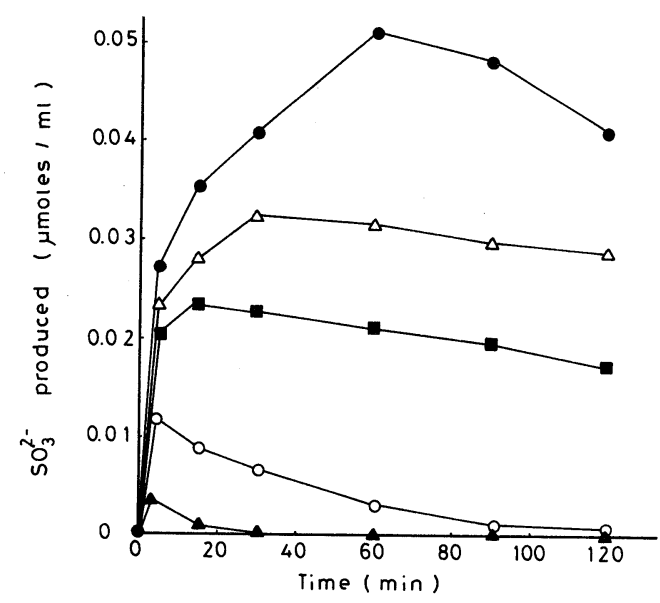

FIG. 1. Production of Sulfite during Aerobic Sulfur Oxidation by $T$. ferrooxidans AP19-3.

Washed iron-grown cells of $T$. ferrooxidans AP19-3 ${ }^{11)}$ ( $5 \mathrm{mg}$ protein) were incubated under aerobic conditions with $2 \%$ elemental sulfur in $10 \mathrm{ml}$ of $0.5 \mathrm{M} \beta$-alanine- $\mathrm{SO}_{4}^{2-}$ buffer, pH $3.0(\mathbf{\Delta}), \mathrm{pH} 4.0(\bigcirc), \mathrm{pH} 5.0(\mathbf{\square}), \mathrm{pH} 6.0(\mathbf{\Delta})$ and $\mathrm{pH} 6.5(\bigcirc)$, respectively. Sulfite in the incubation mixtures was determined spectrophotometrically by the pararosaniline method. ${ }^{15)}$ 


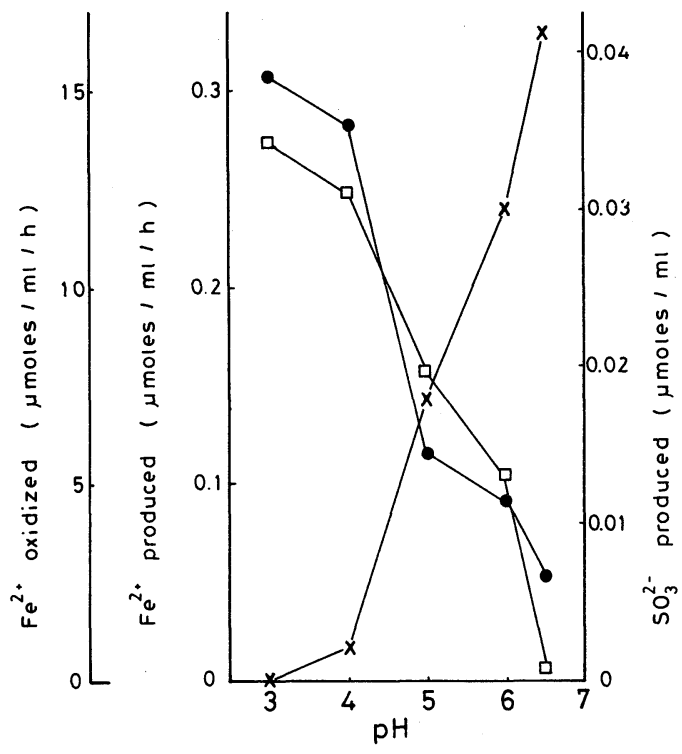

FIG. 2. Activities of the Ferric-ion Reducing and Ironoxidizing Systems in $T$. ferrooxidans AP19-3 after Incubation of the Cells with Elemental Sulfur under Aerobic Conditions.

Washed iron-grown cells of $T$. ferrooxidans AP19-3 ${ }^{11)}$ ( $5 \mathrm{mg}$ protein) were incubated under aerobic conditions with $2 \%$ elemental sulfur in $10 \mathrm{ml}$ of $0.5 \mathrm{M} \beta$-alanine- $\mathrm{SO}_{4}^{2-}$ buffer, $\mathrm{pH} 3.0,4.0,5.0,6.0$ and 6.5, respectively, for $2 \mathrm{hr}$. The treated cells were harvested and then washed three times with $0.1 \mathrm{M} \beta$-alanine- $\mathrm{SO}_{4}^{2-}$ buffer, $\mathrm{pH}$ 3.0. The activities of the ferric-ion reducing system and iron oxidase were determined by the same methods as described previously. ${ }^{11)}$ Symbols: 0 , the activity of the ferric-ion reducing system; $\square$, the activity of iron oxidase; $\times$, sulfite in the incubation mixture after $2 \mathrm{hr}$.

cells, in particular, at acidic $\mathrm{pH}$. We previously reported that $T$. ferrooxidans AP19-3 could oxidize sulfite enzymati-

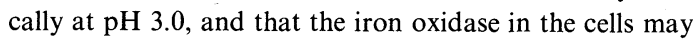
be involved in sulfite oxidation. ${ }^{11)}$

Cells incubated with elemental sulfur for 2 hours under the same experimental conditions as in Fig. 1 were harvested and washed three times with $0.1 \mathrm{M} \beta$-alanine$\mathrm{SO}_{4}^{2-}$ buffer, pH 3.0, and then their iron-oxidizing and FIR systems were examined. As shown in Fig. 2, 2 hours incubation did not affect either of the enzyme activities in the cells that were incubated with elemental sulfur at $\mathrm{pH}$ 3.0 and 4.0. In contrast, both of the enzyme activities in the cells that were incubated with elemental sulfur at $\mathrm{pH} 6.5$, 6.0 and 5.0 were markedly decreased. The extent of the decrease in these enzyme activities was very closely related to the amount of sulfite remaining in the incubation mixture after 2 hours. The results indicate that not only externally added sulfite but also the sulfite produced by the cells themselves during the sulfur oxidation has a harmful

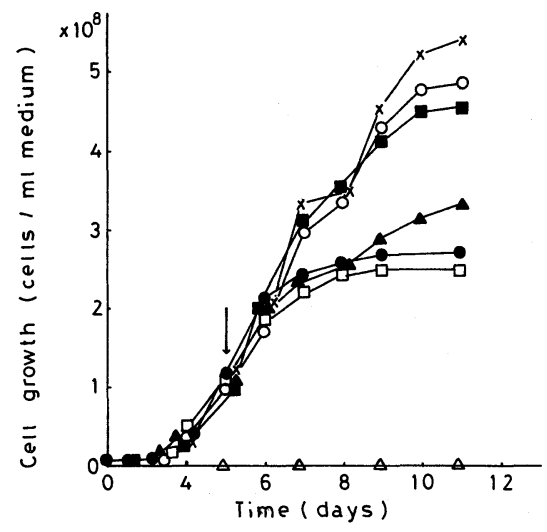

FIG. 3. Effects of Sulfite and Ferric Ions on the Growth of $T$. ferrooxidans AP19-3 on a Sulfur-salts Medium.

The composition of the sulfur $(1 \%)$-salts medium and the method for determining cell growth were described previously. ${ }^{14)}$ Sulfur-grown cells of $T$. ferrooxidans AP19-3 were inoculated into and then cultured in the sulfur $(1 \%)$ salts medium, pH 3.0, for 5 days. Symbols: $\square, 1$ mM sulfite was added to the medium at the time indicated by the arrow; both $1 \mathrm{~mm}$ sulfite and $\mathrm{Fe}^{3+}$ [3.6 mM (O), $7.2 \mathrm{~mm}$ $(\mathbf{A}), 18 \mathrm{~mm}(\square)$ and $36 \mathrm{~mm}(\times)$, respectively were added to the medium at the time indicated by the arrow; $\bigcirc$, neither $1 \mathrm{~mm}$ sulfite nor $\mathrm{Fe}^{3+}$ was added.

\section{effect on the cells.}

When $0.5 \mathrm{~mm}$ sulfite was added to the sulfur $(1 \%)$ salts medium, $\mathrm{pH} 3.0$, at the start of the cultivation, the growth of $T$. ferrooxidans AP19-3 was completely inhibited (data not shown). After 5 days cultivation in the sulfur $(1 \%)$-salts medium, $\mathrm{pH} 3.0$, without sulfite, $1 \mathrm{~mm}$ sulfite was added to the medium. This treatment caused complete growth inhibition. If $\mathrm{Fe}^{3+}$ was added simultaneously to the above medium containing $1 \mathrm{~mm}$ sulfite, the growth inhibition by sulfite was not observed (Fig. 3). The finding that the growth inhibition caused by sulfite decreased in proportion to the increasing amount of $\mathrm{Fe}^{3+}$ added to the medium suggests that sulfite was chemically oxidized by $\mathrm{Fe}^{3+}$ to give $\mathrm{SO}_{4}^{2-}$ and $\mathrm{Fe}^{2+}$, and the latter was then oxidized by the iron oxidase in the cells to regenerate $\mathrm{Fe}^{3+}$.

The results presented in this paper suggest the possibility that both the active iron oxidase in the investigated strain and $\mathrm{Fe}^{3+}$ in the medium play important roles in the detoxification of the sulfite produced during the oxidation of elemental sulfur, and also reasonably explain why $T$. ferrooxidans can vigorously utilize sulfide ores in such an acidic environment that $\mathrm{Fe}^{3+}$ is present at high concentration.

\section{REFERENCES}

1) J. Landesman, D. W. Duncan and C. C. Walden, 
Can. J. Microbiol., 12, 957 (1966).

2) M. Silver and D. G. Lundgren, Can. J. Biochem., 46, 457 (1968).

3) M. Silver and D. G. Lundgren, Can. J. Biochem., 46, 1215 (1968).

4) M. Silver, Can. J. Microbiol., 16, 845 (1970).

5) J. R. Vestal and D. G. Lundgren, Can. J. Biochem., 49, 1125 (1971).

6) O. H. Tuovinen, B. C. Kelly and D. J. D. Nicholas, Can. J. Microbiol., 22, 109 (1976).

7) M. Eccleston and D. P. Kelly, J. Bacteriol., 134, 718 (1978).

8) D. P. Kelly, Phil. Trans. R. Soc. London Ser. B, 298, 499 (1982).
9) I. Suzuki, Biochim. Biophys. Acta, 104, 359 (1965).

10) I. Suzuki and M. Silver, Biochim. Biophys. Acta, 122, 22 (1966).

11) T. Sugio, C. Domatsu, O. Munakata, T. Tano and K. Imai, Appl. Environ. Microbiol., 49, 1401 (1985).

12) T. Sugio, W. Mizunashi, T. Tano and K. Imai, Agric. Biol. Chem., 50, 2755 (1986).

13) T. Sugio, K. Wada, W. Mizunashi, K. Imai and T. Tano, Agric. Biol. Chem., 50, 2917 (1986).

14) T. Sugio, C. Domatsu, T. Tano and K. Imai, Appl. Environ. Microbiol., 48, 461 (1984).

15) P. W. West and G. C. Gaeke, Anal. Chem., 28, 1816 (1956). 